\title{
POLITIKLAGERS BEHANDLING — ET SPØRGSMÅL OM TILLID
}

\author{
Af Peter Blume, Annette Esdorf, Henning Glahn, Henning Koch \\ og Henning Steensig, København*)
}

\begin{abstract}
»Der er næppe noget, der er så skadeligt for et godt forhold mellem politi og borgere, som mistanke om, at man hos politiet kan blive udsat for uberettiget magtanvendelse. Ligesom Cæsar lod sig skille fra sin hustru, fordi der var rejst (ubegrundet) tvivl om hendes dyd, således skades forholdet mellem politi og borgere, blot politiet mistænkes for magtmisbrug, selv om mistanken afkræftes.«
\end{abstract}

Rigspolitichef E. Heide-Jørgensen i lærebogen »Politikundskab«.

\section{Et forslag til nye regler}

Dansk Retspolitisk Forenings arbejdsgruppe vedr. retssikkerhed i retsplejen har d. 11.3.80 tilsendt Folketingets retsudvalg og justitsministeriet et forslag til nye regler for klager over politipersonalets adfærd. Forslagets hovedpunkter, jvf. fig. 1, er følgende:

1. Klager, der indbringes for et politiklagenævn, skal som en altovervejende hovedregel gøres til genstand for en undersøgelse, jfr. dog pkt. 7.1 .

2. Undersøgelser iværksættes og kontrolleres af et af ialt 54 politiklagenævn, hvert dækkende en af landets politikredse.

3. Et politiklagenævn består af en politiombudsmand og fire nævnsmedlemmer.

4. Folketingets ombudsmand udnævner landets 3 politiombudsmænd (for hhv. Jylland, Øerne og København) efter ansøgning blandt forsvarsadvokater med mindst 5 års erfaring.

*) Forfatterne er medlemmer af arbejdsgruppen vedr. retssikkerhed i retsplejen under Dansk Retspolitisk Forening. Arbejdsgruppen, der siden sin oprettelse i oktober 1978 har bestået af $\mathrm{ml}$. 10-15 medlemmer fra anklagemyndigheden, centraladministrationen, advokatstanden, domstolene og universitetet, har tidligere arbejdet med spørgsmålet om forsvarerudelukkelse og i skrivelse af 8.3.79 til retsudvalget behandlet justitsministeriets lovforslag nr. 89 af 29.11 .78 til ændring af retsplejeloven (Rpl. $§ 214$ stk. 3, 2. pkt., 847 stk. 1, 2. pkt., 965 c stk. 4 og 965 d). 
5. Nævnsmedlemmer udpeges for 2 år ad gangen efter reglerne om lægdommere. Kun halvdelen afgår hvert år for at sikre fornøden kontinuitet.

6. Undersøgelser foretages af politiombudsmanden (ikke af politiet selv).

7. Politiklagenævnet har kompetence til:

7.1 at forhåndsafvise åbenbart urimelige klager

7.2 efter en undersøgelse at træffe beslutning om afvisning eller beklagelse

7.3 efter en undersøgelse at træffe beslutning om rejsning af disciplinærsag eller straffesag (politiklagenævnet tillægges m. a. o. en 'anklagefunktion').

8. Politiombudsmanden fører såvel disciplinærsager som straffesager.

9. Afgørelse i disciplinærsager hhv. straffesager træffes som hidtil af politimestre hhv. domstolene.

10. Forhandlingerne i politiklagenævnene er offentlige, men der skal på begæring udstedes navneforbud. Der kan på begæring rent undtagelsesvis udstedes referatforbud.

For så vidt angår de gældende regler og et alternativt forslag til nye regler henvises til landsretssagfører J. Schultz-Lorentzens artikel i Juristen og Økonomen 1980 s. 78 ff.

\section{Baggrunden for arbejdsgruppens forslag}

Det er gruppens opfattelse, at en fortsat kritik af behandlingen af klager over politiet er uacceptabel, idet den ikke tjener hverken befolkningens eller politiets interesse. Dels fordi den nedbryder befolkningens tillid til politiet i almindelighed, og dels fordi den i særdeleshed begrænser klageordningens effektivitet. En manglende tillid vil medføre, at berettigede klager ikke bliver indbragt for lokalnævnet. Det er væsentligt at være opmærksom på, at disse argumenter for en ændring er gyldige, selvom den konkrete klagebehandling i dag i det store og hele måtte være grundig nok. Fra et retssikkerhedssynspunkt er det afgørende, at klageordningen er således indrettet, at den minimerer risikoen for misbrug, og at befolkningen føler sig overbevist herom. Det skal dog bemærkes, at der ikke findes undersøgelser - hverken egentlig videnskabelige eller opinionsundersøgelser - der har klarlagt befolkningens holdning, herunder en evt. skiftende holdning, til den gældende klageordning. Det er imidlertid en rimelig formodning, at massemediernes behandling, der naturligvis indgår i befolkningens bevidsthed, navnlig på lang sigt kan være holdningsskabende.

En medvirkende årsag til den bestående utryghed ved den nuværende klageordning er vores helt utilstrækkelige viden om klagesagernes udvikling og indhold. De officielle statistikker er mildt sagt ubrugelige. Vi ved intet om, hvorvidt klagesagernes antal set på landsplan er steget eller faldet, eller 
hvorvidt der er sket en ændring i indholdet af klagerne, således at der eksempelvis klages oftere nu end før over vold og hårdhændet behandling.

Justitsministeriet har i 1977 udarbejdet en statistik over de første fire år under den nye klageordning, men denne statistik indeholder ingen af disse oplysninger.

Fra og med 1978 offentliggøres i Politiets Årsberetning en oversigt vedrørende klagesager mod polititjenestemænd. Denne statistik er ligeledes kun en oversigt over den formelle sagsbehandling, mens den intet siger om klagernes karakter.

På grund af den mangelfulde viden har den offentlige debat både fra kritikernes og politiets side ofte været ført på et løsagtigt grundlag. Det skal navnlig fremhæves, at det faktum, at mere end $90 \%$ af klagesagerne afvises som åbenbart grundløse eller som værende af uvæsentlig betydning, selvsagt ikke i sig selv kan føre til den konklusion, at klageordningen er dårlig. Resultatet kan imidlertid heller ikke føre til den modsatte konklusion: at ordningen er god nok.

Når det alligevel er et rigtigt standpunkt på det foreliggende grundlag at forkaste den nuværende ordning, skyldes det navnlig to forhold. For det første, at klagerne i praksis oftest afvises uden en undersøgelse, efter at de indklagede politifolk har givet en skriftlig redegørelse for deres egen adfærd, og uden at klageren gøres bekendt med redegørelsen og får lejlighed til at kommentere den. Polititjenestemandens ret til kontradiktion (Rpl. $\S$ $1019 \mathrm{~d}$ stk. 1) erstatter i realiteten en egentlig undersøgelse (se Vejledning nr. 51 af 22. 3. 78 pkt. G 2 (Min.tid. s. 226 f.). For det andet, at det både principielt og reelt er forkert, at politiet selv foretager den egentlige undersøgelse af klager over politiet, som den gældende klageordning foreskriver og forudsætter.

Justitsministeren (Nathalie Lind) udtalte d. 26. 4. 79 i folketinget under en forespørgsel om politiet:

"En sådan tingenes tilstand er uholdbar set fra befolkningens side, idet den kan være med til at undergrave tilliden til politiet, men den er, som jeg allerede har været inde på, også uheldig set med politiets øjne, og disse forhold er baggrunden for mine overvejelser om behovet for at indføre ændrede procedurer for behandlingen af klager over politiets adfærd. Som følge af den rejste kritik må overvejelserne særlig koncentreres om en ændret sammensætning af lokalnævn ved klagebehandlingen.»

Arbejdsgruppens arbejde skal derfor også ses som et konkret forslag til den ændring af klageordningen, som justitsministeren har bebudet vil komme.

\section{Nogle lal vedr. den geldende og tidligere klageordninger}

Ifølge den af justitsministeriet udarbejdede statistik for perioden 1.10.7330.9. 77 afviste lokalnævnet/klageudvalg/formanden at iværksætte en un- 
dersøgelse af klagen i $93 \%$ af tilfældene med den begrundelse, at klagen blev fundet åbenbart grundløs, at klagen angik forhold af uvæsentlig betydning, at klageren undlod at fremkomme med oplysninger om grundlaget for klagen eller at klagen blev indgivet mere end 6 måneder efter det forhold, der blev klaget over, var begået. Der er ingen tvivl om, at de to første begrundelser er langt de almindeligste. Vedrørende $6 \%$ af klagerne besluttedes det, at klagen skulle undersøges af statsadvokaten, hvilket i praksis betyder, at politipersonale udpeget af rigspolitichefen foretager undersøgelsen (jvf. jm. bekendtgørelse nr. 506 af 13.12. 73 \$ 21 stk. 3). I $1 \%$ af tilfældene blev undersøgelsen foretaget ved retten. Der er m. a. o. tale om, at den helt overvejende del af alle klagesager afvises uden nærmere undersøgelse alene på baggrund af den forurettedes klage og den eller de indklagede politifolks oplysninger og bemærkninger, som de er nedfældet i deres egne notitser. Det er denne kategori af klagesager, der i den nye statistik i Politiets Årsberetning fra 1978 betegnes som »Sagen fundet tilstrækkelig oplyst«, medens dette begreb efter loven er reserveret til lokalnævnets afgørelse efter en egentlig undersøgelse.

Det er interessant i denne forbindelse at kaste et blik tilbage på, hvordan klagerne blev undersøgt efter den gamle ordning før 1973, dens manglex iøvrigt ufortalte. I betænkning nr. 507/68 vedrørende undersøgelser mod personer ansat i politiets tjeneste siges det (s. 9): »... sagerne afgøres som oftest på grundlag af den foreliggende klage og de i denne anledning indhentede udtalelser fra de implicerede polititjenestemænd. I alle sager af nogen betydning foretages der tillige en afhøring til rapport af klageren og de af denne opgivne vidner, ligesom man i sager, hvor det skønnes at have betydning, afhører den eller de indklagede politifolk." Udvalget indsamlede endvidere et statistisk materiale over alle klager over politifolk i årene 1964 og 1965. Ifølge dette materiale blev på landsplan ialt $30 \%$ af alle klager undersøgt ved afhøring af klageren og indklagede (og evt. vidner) eller ved afhøring af klageren og indhentelse af notits eller rapport fra den indklagede. I Københavns politikreds, der havde den mest udførlige statistik, blev $43 \%$ af klagerne undersøgt på denne måde. Dertil skal lægges de tilfælde, hvor der blev foretaget en egentlig politimæssig undersøgelse med henblik på eventuel straffesag eller tjenestemandsforhør (Betænkningen s. 37 Tabel 2).

Efter den gældende ordning skal der, uanset om klagen underkastes en undersøgelse eller ej, træffes en afgørelse i klagesagen. Denne afgørelse træffes typisk af politimesteren, ellers af statsadvokaten eller retten. Politimesteren kan afvise sagen som ubegrundet, han kan beklage det passerede, eller han kan påtale det overfor den indklagede. Politimesterens afgørelse kan indankes for justitsministeriet.

Ifølge den nævnte statistik blev $90 \%$ af de sager, hvori politimesteren traf afgørelsen, afvist som ugrundede, $4 \%$ førte til en beklagelse, og $6 \%$ førte til en påtale evt. tillige en beklagelse. 
Også her er det perspektivrigt at se på det nævnte statistiske materiale vedr. ordningen før 1973. I $30 \%$ af klagerne (excl. sager med efterforskning mod polititjenestemænd som sigtede og disciplinærsager) fik klageren helt eller delvist medhold, og kun i $70 \%$ af tilfældene blev klagen afvist (for at kunne sammenligne med den nyere statistik er klager, der beroede på misforståelser, tilbagekaldte klager og klager, der blev henlagt uden skriftligt svar, udeladt af beregningen). (Betænkningen s. 39 - Tabel 3 III).

Politimesteren kan endvidere træffe afgørelse om iværksættelse af disciplinærforfølgning, efter klagesagens behandling i lokalnævnet er afsluttet. Dette skete i $1 \%$ af samtlige klagesager.

Hvis der under sagens behandling viser sig at være grundlag for at rejse sigtelse mod den indklagede, slutter behandlingen af klagesagen i lokalnævnet, og undersøgelse indledes af statsadvokaten. Dette skete i $1 \%$ (18 tilfælde) af alle klagesagerne. Statsadvokaten kan, som i andre sager, opgive påtale, hvorefter sagen genoptages i nævnet. 2 sager var ved statistikkens opgørelse ikke afgjort, 14 sager endte med påtaleopgivelse.

Hvis der rejses tiltale, er det selvsagt domstolene, der træffer afgørelse om domfaldelse eller frifindelse. I den fireårige periode blev der rejst tiltale i 2 tilfælde, der begge førte til frifindelse. Hvis den indklagede frifin. des, genoptages sagen ligeledes i lokalnævnet.

\section{Hvad rettede den lidligere kritik sig imod?}

For at forstå kritikken i dag er det helt afgørende at være opmærksom på, hvad den tidligere kritik rettede sig imod, og hvilken klageordning vi fik på baggrund af denne kritik.

Efter at forskellige klageordninger var drøftet af et udvalg nedsat i 1966 (bet. nr. 507/68) og af strafferetsplejeudvalget (bet. nr. 622/71), blev loven af 1973 gennemført efter forslag fra justitsministeriets »strukturudvalg vedrørende politiet « (se forslag til lov om ændring af retsplejeloven etc. med bilag i Folketingstidende tillæg A sp. 4769 ff. fra Folketingsåret 1972-73).

\subsection{Bet.nr. 507/68}

Det fremgår af betænkning 507/68, at baggrunden for udvalgets nedsættelse var den offentlige debat, der udtrykte kritik af den gældende ordning, »hvorefter undersøgelserne foretages af politiets egne folk«. Debatten gav anledning til et spørgsmål i folketinget (13.4.66) fra højesteretssagfører Ib Thyregod:

„Vil justitsministeren foranledige, at der gennem retsplejerådet foretages overvejelse af mulighederne for, at undersøgelser mod polititjenestemænd fremover foretages gennem et af politiet uafhængigt organ?"

Spørgeren gjorde $\mathrm{i}$ begrundelsen gældende, »at det ud fra et retssikkerhedssynspunkt ville være rimeligt, at et af politiet uafhængigt organ fore- 
tager disse undersøgelser... Han fandt endvidere, at selvom politiet naturligvis ønsker at være fuldt objektive, er det uheldigt med en sådan selvkontrol. Der kan naturligvis finde en efterfølgende kontrol sted, dels gennem en domstolsbehandling, dels gennem ombudsmandsinstitutionen, men der vil da foreligge politirapporter udfærdiget af politiet, og de forklaringer, der her er afgivet, vil have en vis tendens til at sætte sig fast, således at det bliver vanskeligt for domstolen eller ombudsmanden at komme til bunds $\mathrm{i}$ sagen «. Justitsministeren mente, at undersøgelserne havde været grundige, objektive og fuldt betryggende, men var dog enig i, at man kunne rejse spørgsmålet om, hvorvidt ordningen er i overensstemmelse med principielle retssikkerhedssynspunkter (se betænkning nr. 507 s. 14).

Udvalget beskrev problemstillingen således:

"Problemet er spørgsmålet om, hvorledes undersøgelserne foretages, altså hvorledes de oplysninger tilvejebringes, som foranlediges af klagen. Selv den mest oprigtige vilje til at yde klageren retfærdighed vil komme til kort, hvis det materiale, hvorpå afgørelsen skal bygges, er misvisende eller ufuldstændigt. $\mathrm{Og}$ selv om mangler og urigtigheder måtte blive påvist under sagens gang, vil det kunne være vanskeligt eller umuligt at »rette sagen op«, fordi bevis kan være gået tabt $\mathrm{i}$ mellemtiden.

Der kan derfor anføres principielle betænkeligheder imod, at politiet selv foretager undersøgelsen i anledning af en klage over en politimand. Selv om man ser bort fra forvanskning eller undertrykkelse af bevismateriale, kan selve følelsen af solidaritet med en kollega, hensynet til politiets prestige og lignende betragtninger være en belastning for en effektiv og upartisk undersogelse af klagesagen....

Det er derfor spørgsmålet om tilvejebringelsen af oplysningerne i klagesagen, der navnlig har været genstand for udvalgets overvejelser.« (Betænkningen s. 31).

Alle udvalgets medlemmer, d.v.s. også rigspolitichefen, repræsentanten for politimestrene, repræsentanterne for de to politiorganisationer og repræsentanten for politifuldmægtigene, var enige om, at det var ukorrekt, principielt set, at politiet selv foretager undersøgelserne. Som udtrykt af flertallet (der kun udgjordes af repræsentanter for politiet): ». . . at det er principielt forkert, at klager over politiet undersøges af politiet selv, kan vi tilslutte os... ud fra det synspunkt, at misbrug af politiets myndighed ville være særlig farlige...«(s. 52).

Dette synspunkt blev imidlertid krydset af andre principielle betragtninger. Flertallet ville alligevel ikke modsætte sig en almindelig auditørordning, hvis den kom til at omfatte såvel klager over en konflikt mellem politi og borger som politifolks lovovertrædelser i almindelighed, f. eks. berigelseskriminalitet og spirituskørsel. Flertallet mente m. a. o., at principielle retssikkerhedssynspunkter kunne bære indførelsen af en auditørordning.

Et mindretal (bestående af en højesteretsdommer, en statsadvokat og en 
person udpeget af folketingets ombudsmand) gik uden forbehold ind for et selvstændigt undersøgelsesorgan ud fra retssikkerhedssynspunkter.

Et andet mindretal mente, at praktiske effektivitetshensyn vejede tungere end de principielle retssikkerhedshensyn, hvorfor politiet fortsat burde foretage afhøringer af politifolk.

\subsection{Lovforslaget fra 1973}

Mens den offentlige kritik, den politiske debat og overvejelserne i betænkning nr. 507/68 sigtede mod at fratage politiet retten til at undersøge sagerne selv og tillægge et uafhængigt organ den fulde kontrol over undersøgelsen ud fra hensynet til retssikkerheden, står udspillet i 1972 fra justitsministeriets strukturudvalg i skierende kontrast hertil. Hensynet til effektiviteten bliver efter dette forslag i praksis næsten enerådende.

I bemærkningerne til lovforslaget fra 1973 siges det (s. 22): ». . det (er) ikke tanken helt at udelukke politiet fra at deltage i undersøgelsen af klagesager«. Der henvises ivrigt til strukturudvalgets bemærkninger til forslaget. Af disse fremgår følgende (lovforslagets s. 37):

»Det er sâvel af hensyn til klageren som af hensyn til den indklagede polititjenestemand af central betydning, at sagerne fremmes med fornøden hurtighed og effektivitet. En retlig undersøgelse vil i almindelighed være mere tidkrævende og omstændelig end en undersøgelse foretaget af statsadvokaten og kan endvidere være mere belastende for såvel klageren som den indklagede. Såfremt der ikke i de enkelte tilfælde er væsentlige modstående hensyn, bør undersøgelsen derfor i almindelighed foretages af statsadvokaten... Statsadvokaten kan gennemfore undersøgelsen personligt eller overlade den til en af sine medarbejdere. Han kan også vælge at benytte polititjenestemænd til at bistå sig, idet det næppe er hverken rimeligt eller muligt at udelukke statsadvokaten fra - i lighed med, hvad der måtte gælde ved en egentlig auditørordning - at trække på den sagkundskab, der er tilstede i politiet«.

Som det vil ses, beskrives klagerens og den indklagedes interesser som fælles, og de peger i retning af en prioritering af hensynet til effektiviteten fremfor hensynet til retssikkerheden.

De refererede argumenter for, at undersøgelsen $i$ almindelighed bør foretages af statsadvokaten, er ord til andet genoptrykt i justitsministeriets vejledning af 22.3.78 vedrørende behandlingen af klagesager. Fra at være løsere forudsætninger for loven er de således blevet mere bindende synspunkter.

Som den korte gennemgang af den tidligere debat klart har dokumenteret, var hele formålet med udvalgsarbejderne at få en egentlig samtidig kontrol med undersøgelsen af klagen. I stedet har vi i realiteten fået et system med efterfolgende kontrol. Politiet kan foretage foreløbige undersøgelser til en tydeliggørelse af klagen inden forelæggelsen i lokalnævnet, de indklagede 
polititjenestemænd udfærdiger selv notitser over egen adfærd til brug for lokalnævnets afgørelse af, om der skal iværksættes en nærmere undersøgelse, og hvis en sådan iværksættes, er det polititjenestemænd, der foretager afhøringer etc.

I bet. 507 nævnes faktisk en sådan lignende klageordning som en af de mange muligheder for nye ordninger, idet udvalget overvejede at genoplive de gamle, sjældent oprettede politiråd og give dem en ny kompetence (med hensyn til en eventuel genoptagelse af politimesterens afgørelse). Dette forslag blev i udvalgets konklusioner ikke specielt fremhævet, men politiets repræsentanter viste en vis interesse for det. De af udvalgets medlemmer, der positivt gik ind for et selvstændigt klageorgan, tog nærmest afstand fra tanken: »Og særlig må det fremhæves, at en sådan blot efterfølgende kontrol ikke afhjælper selve den mangel ved den bestående ordning, som har valit kritik“ (s. 50).

Det samlede udvalg gav dog følgende vurdering af en sådan ordnings konsekvenser, hvis den blev gennemført: »Men selve den omstændighed, at saintlige sager mod politimænd forelægges et udvalg med repræsentanter for of fentligheden, vil utvivlsomt styrke tilliden til, at der finder en effeiktiv og upartisk undersøgelse sted og give øget mulighed for drøftelser af reforme med hensyn til politiets arbejde« (s. 49).

\subsection{Konklusion}

Det kan således slås fast, at loven fra 1973 ikke forsøgte at imødekumme det centrale punkt $i$ kritikken: kravet om en undersøgelse, der ikke blev fareingel af politiet selv, men af et uafhangigt klageorgan. Dette faktum blev i det store og hele overset $\mathrm{i}$ den offentlige debat omkring lovens vedtagelse og overses også oftest i dag.

\section{Forslag til ny klageordning}

\section{j.1. Politiombudsmcend (undersøgelsesfasen)}

Et centralt element i en ny klageordning må være, at politiet ikke deltager $i$ undersogelsesfasen. Politiets deltagelse på dette stadium af sagen er ikke betryggende for den borger, der har klaget, og ej heller acceptabelt for offentligheden.

Statsadvokaturen er imidlertid heller ikke et tilstrækkeligt uafhængigt organ til at forestå undersøgelsen, idet der ikke eksisterer en tilstrækkelig klar funktionsdeling mellem statsadvokatur og politi: Dels har politiet i en række sager selvstændige anklagefunktioner, dels samarbejder politiet i andre sager som underordnet anklagemyndighed med statsadvokaturerne og dels er statsadvokaturernes personel oftest hentet fra politikredsene, idet politifuldmægtige som led $\mathrm{i}$ en turnusordning midlertidigt gør tjeneste i statsadvokaturerne og herefter sendes tilbage til politikredsene. Der fore- 
\begin{tabular}{l} 
딩 \\
0 \\
0 \\
0 \\
0 \\
0 \\
0 \\
\hline 0 \\
0 \\
0 \\
0 \\
5 \\
0 \\
0 \\
5 \\
5
\end{tabular}

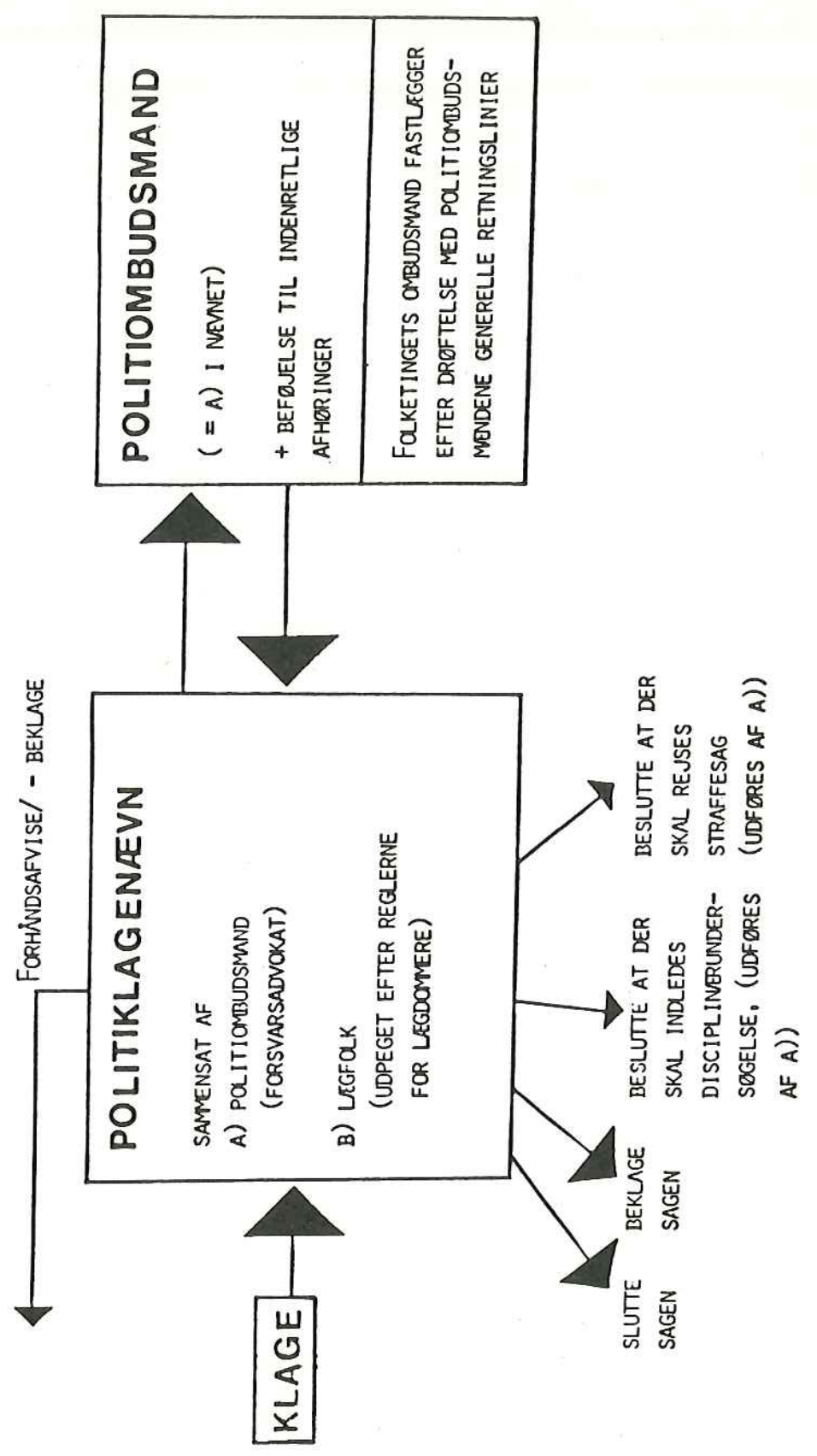


ligger derfor en vis professionel samhørighed og forståelse, der kan være hæmmende for en uvildig holdning ved undersøgelsen af en klage.

Arbejdsgruppen finder på den anden side, at det er væsentligt, at den person eller det organ, der skal gennemfore undersøgelsen, har et grundigt kendskab til politiets arbejdsmetoder og forhold. Gruppen skal derfor foreslå, at undersøgelsen varetages af en forsvarsadvokat, der er vant til at stå som modpart over for det statslige retssystem. En forsvarers varetagelse af undersøgelsesfunktionen, hvor indenretlige afhøringer kan foretages, vil ligeledes være mere i overensstemmelse med almindelige retssikkerhedssynspunkter. Da disse undersøgelser må forudsætte en vis rutine og tid til at tage tilstrækkelige initiativer, vil det ikke være tilstrækkeligt, at en hvilken som helst advokat kan beskikkes ad hoc til at undersøge en klages holdbarhed. Der bør derfor oprettes selvstændige stillinger, hvor en forsvarsadvokat, der opfylder den betingelse at have fungeret som forsvarer i f. eks. 5 år, som deltids- eller evt. heltidsansat har til opgave at undersøge klagerne. Denne forsvarer kan benævnes politiombudsmand. Det foreslås, at de enkelte politiombudsmænd udpeges af folketingets ombudsmand.

Arbejdsgruppen finder det hensigtsmæssigt, at der sker en vis decentralisering, hvorfor der ikke foreslås oprettet en egentlig politiombudsmandsinstitution. Det er indgående blevet drøftet, hvor mange politiombudsmandsstillinger der bør oprettes. Ressourcemæssige hensyn og det forventede antal klager taler for, at antallet af disse stillinger er begrænset. Gruppen foreslår derfor, at der oprettes 3 politiombudsmandsstillinger, hvis funktionsområde er hhv. Jylland, Øerne og København. Selvom ikke alle klagesager bør undersøges, jfr. nedenfor, vil der efter det hidtidige klageantal, der med en forbedret klageordning må antages at ville stige, være et tilstrækkeligt antal sager til at beskæftige 3 politiombudsmænd på hel- eller deltid.

Uanset at en decentralisering må betragtes som et gode, er det også nødvendigt, at der etableres en nogenlunde ensartet praksis. Det foreslås derfor, at folketingets ombudsmand udstikker generelle retningslinier for klagernes behandling efter en drøftelse med de 3 politiombudsmænd; en sådan drøftelse bør finde sted hvert år.

I bet. nr. 507/68 diskuterede man, som omtalt ovenfor, indførelsen af en politiauditørordning. Et argument imod denne ordning var, at et sådant organ hurtigt ville blive identificeret med politiet. Arbejdsgruppen har vanskeligt ved at forestille sig en lignende »anklage « rettet mod den nuværende ombudsmand, således at denne $\mathrm{i}$ dag skulle kunne opfattes som identisk med den administration, han kontrollerer. Analogt hermed må det antages, at de her foreslåede politiombudsmænd ikke $\mathrm{i}$ offentligheden vil blive udsat for en sådan identifikation.

\subsection{Politiklagencevn (selektions- og afgorelsesfasen)}

For så vidt angår selektions- og afgørelsesfasen foreslås også nye regler. 


\subsubsection{Ncevnenes sammenscelning}

Det er arbejdsgruppens opfattelse, at spørgsmålet om grænserne for politiets tilladelige adfærd i høj grad er et samfundspolitisk spørgsmål, hvilken erkendelse iøvrigt også må antages at ligge til grund for de gældende regler om lokalnævns sammensætning. Eksempelvis er spørgsmålet om den nødvendige og forsvarlige fysiske magtanvendelse ikke et spørgsmål, der alene kan afgøres ud fra en juridisk bedømmelse. Arbejdsgruppen finder det derfor rimeligt, at lægfolk har en så stor indflydelse på disse sagers behandling som muligt.

På denne baggrund foreslås oprettet et politiklagenævn i hver af landets 54 politikredse. Disse politiklagenævn sammensættes af 4 lægfolk, der i lighed med reglerne for nævninge og domsmænd er udtaget ved lodtrækning fra lister udarbejdet af de kommunale grundlisteudvalg. Hertil kommer den regionale politiombudsmand, som er formand for nævnet. Det enkelte politiklagenævn indkaldes af politiombudsmanden, når han under hensyn til antallet (evt. arten) af klagesager finder det fornødent.

For at tilgodese på den ene side hensynet til kontinuiteten (en del sager vil strække sig over flere nævnsmøder) samt tilvejebringelsen af den fornødne erfaring i sagsbehandlingen $o g$ på den anden side hensynet til at undgå for stor »professionalisme« hos de læge medlemmer i nævnet, foreslås det, at lægmedlemmerne deltager i nævnet i 2 år, og at halvdelen udskiftes hvert år.

Den mest markante ændring i forhold til den gældende ordning er, at politiet ikke er reprcesenteret $i$ politiklagencevnene. Selvom arbejdsgruppen lægger størst vægt på, at politiet ikke deltager i undersøgelsen, foreligger der dog også gode grunde til, at politiet ikke skal deltage i den øvrige sagsbehandling, herunder afgørelsen. Det er ikke acceptabelt, at en embedsmandsgruppe selv medvirker ved fastlæggelsen af grænserne for denne gruppes lovlige virksomhed. Det må i denne forbindelse antages, at selv en mindre deltagelse af politirepræsentanter i politiklagenævnene vil medføre, at de standsmæssigt begrundede synspunkter får en for stor vægt i bedømmelsen. Politiets repræsentanter vil med deres særlige viden og status nemt kunne dominere politiklagenævnene. Eftersom politiets standsmæssige synspunkter i de tilfælde, hvor disse måtte være relevante, kan gøres gældende allerede i undersøgelsesfasen (overfor politiombudsmanden), kan det ikke antages, at politiets medvirken i klagenævnet er nødvendig.

\subsubsection{Ncevnenes kompetence}

Politiklagenævnenes kompetence foreslås fastsat på følgende måde:

1) Bagatelagtige klager kan af det samlede nævn forhåndsafvises eller nævnet kan give den pågældende borger en skriftlig beklagelse. 
2) For sager, der er undersøgt af politiombudsmanden, kan nævnet beslutte

a. at slutte sagen,

$b$. at give en beklagelse,

$c$. at rejse straffesag eller disciplinærsag.

I relation til den sidstnævnte kompetence skal anføres, at det i det gældende straffeprocessuelle system er et anerkendt princip, at befolkningen i videst muligt omfang skal have lejlighed til som nævninge eller domsmænd at deltage i den dømmende funktion. Det er en naturlig udvidelse af dette princip, at befolkningen også får indflydelse på det mindre spørgsmål, om en sag skal rejses.

\subsubsection{Offentlighed}

For at sikre den størst mulige offentlige kontrol med politiklagenævnets arbejde bør klagenævnets møder være offentlige. Det er en selvfølge, at også politiet kan overvære nævnets møder. Af hensyn til de implicerede parter foreslås dog, at nævnet på begæring skal udstede navneforbud og ligeledes på begæring kan bestemme referatforbud.

\subsubsection{Straffesag/disciplincerundersøgelse}

I de tilfælde, hvor politiklagenævnet bestemmer, at der skal rejses straffesag eller indledes disciplinærundersøgelse, behandles de pågældende sager af politiombudsmanden, der således fungerer som anklager. For så vidt angår straffesager nødvendiggør denne ordning en ændring af retsplejelovens $\S 720$. Mens det er i overensstemmelse med rpl. § 719, stk. 1, jfr. § 722, stk. 1, nr. 2, at politiklagenævnet som særlig forvaltningsmyndighed beslutter, at der skal rejses tiltale, nødvendiggør politiombudsmandens varetagelse af anklagefunktionen, at $\$ 720$ udvides samtidig med, at der i kap. 65 i retsplejeloven indsæettes en særlig bestemmelse herom. Andre ændringer af retsplejeloven er derimod ikke af denne grund nødvendige. For så vidt angår disciplinærforfølgning må denne finde sted i overensstemmelse med reglerne i tjenestemandsloven (lov nr. 291 af 18/6 1969). Politiombudsmanden fungerer således som forhørsleder, jfr. $§ 20$, stk. 2 og har den i $\$ 21$, stk. 3 og stk. 6 angivne kompetence. Sidstnævnte bestemmelse bør dog ændres således, at politiombudsmanden under alle omstændigheder skal fremkomme med en indstilling til den besluttende forvaltningsmyndighed. Det må endvidere fastsættes, at sagen kun kan sluttes uden gennemførelse af et egentligt tjenstligt forhør, jfr. $\$ 24$, såfremt politiombudsmanden kan acceptere denne afslutning af sagen. 